\title{
Carneiro Leão and the Reform of Foreign Languages in Brazil (1930-1934)
}

\author{
Jonathas de Paula Chaguri' \\ Maria Cristina Gomes Machado" \\ 'Universidade de Pernambuco (UPE), Recife/PE - Brazil \\ "Universidade Estadual de Maringá (UEM), Maringá/PR - Brazil
}

\begin{abstract}
Carneiro Leão and the Reform of Foreign Languages in Brazil (1930-1934). Carneiro Leão's proposal for a reform in the teaching of foreign languagesat secondary school level, at the Colégio D. Pedro II, between 1930 and 1934, is analyzed. Results show that Carneiro Leão was in favor of a foreign language reform featuring an active and dynamic learning process within the context of engagement in the ideals of an active school. In fact, Carneiro Leão gave a new identity to the study of languages, ensuring a convincingly practical and useful teaching, without the disassociation of the characteristics of the Humanities for people who needed training for production means in the country's commerce and industry.

Keywords: Antônio Carneiro Leão. Foreign Languages Reform. Brazilian
\end{abstract} Secondary Education.

RESUMO - Carneiro Leão e a Reforma das Línguas Estrangeiras no Brasil (1930-1934). Objetivamos analisar a proposta de Carneiro Leão para a reforma do ensino de línguas estrangeiras, no ensino secundário no Colégio D. Pedro II, entre 1930 e 1934. Os resultados mostram que Carneiro Leão foi favorável a uma reforma que contemplasse um estudo de forma ativa e dinâmica, possibilitando o engajamento no ideário de uma escola ativa. Com isso, Carneiro Leão inaugurou uma nova identidade ao estudo das línguas, garantindo um ensino contundentemente útil e prático, sem desvincular o caráter de promotor das humanidades aos homens que necessitavam de uma formação para os meios de produção do comércio e da indústria no país.

Palavras-chave: Antônio Carneiro Leão. Reforma das Línguas Estrangeiras. Ensino Secundário Brasileiro.

Educação \& Realidade, Porto Alegre, v. 44, n. 4, e87897, 2019. 
Carneiro Leão and the Reform of Foreign Languages in Brazil (1930-1934)

\section{Introduction}

Antônio Arruda Carneiro Leão (1887-1966), also known as Carneiro Leão, Brazilian teacher and scholar, is one of the most important and respected thinkers involved in educational and social debates during most of $20^{\text {th }}$ century. Among the several educators and reformers in Brazilian historiography, such as Rui Barbosa (1849-1923), Fernando de Azevedo (1894-1974), Anísio Teixeira (1900-1971), Florestan Fernandes (1920-1995) and others, Carneiro Leão is an important person that should be studiedintensely within the academic milieu.

According to Chaguri and Machado (2017), there are at present 26 scholar research works (16 Master's dissertations and 10 Doctoral theses) going on which mention Carneiro Leão's plans and aims for education in Brazil. However, only 8 dissertations and 4 theses, totaling 12 research projects, out of the 26 mentioned by Chaguri and Machado (2017), specifically investigate the educator's educational activities and thoughts within the most different educational aspects.

Research themes are related to sociology, teachers' formation, hygiene in people's formation, school administration and management, universities, educational reform, rural education, secondary schools and popular education. The teaching of foreign languages is another theme related to Carneiro Leão's activities and thought. In fact, in his ideas on foreign languages, Carneiro Leão ideas were thought-provoking not merely in theoretical issues but especially in the teaching didactics of foreign languages.

Several other researchers in the History of Education, such as Araújo (2002), Paulilo and Vidal (2003), Câmara (2003), Silva and Machado (2004), Silva (2006), Machado (2008), Schelbauer and Machado (2013), Lima and Machado (2014), Lima (2011; 2016), have discussed Carneiro Leão within the context of the different professional activities exercised by him as teacher, educator and politician.

Current article discusses Carneiro Leão's proposal for the reform of the teaching of foreign languages, at secondary level, at the Colégio D. Pedro II, Rio de Janeiro, Brazil, when he was the main teacher of French between 1930 and 1934. It was the period when he was responsible for disseminating and implementing ideas for the reform of foreign languages.

This articleis divided into four sections so that results could be better presented to the reader. The first section gives a general overview of current analysis. The second section exhibits Carneiro Leão's biographical notes, while in the third section a discussion ensues on a set of activities and efforts to establish a type of instruction that would turn dynamic the study of foreign languages with regard to the social needs of the 1930-1934 period. The fourth section, titled Conclusion, analyzes the text as a whole and provides the sources used for the writing of the text. 


\section{(Un)known Carneiro Leão in the reform for the teaching of foreign languages}

Antônio Arruda Carneiro Leão was born in Recife, state of Pernambuco, Brazil, on July 2, 1887, and died in Rio de Janeiro, Brazil, on October 3, 1966. He was bred within a culture-minded family pertaining to the Brazilian elite population. Hailing from a traditional family from Pernambuco, he was the son of Elvira Cavalcanti de Arruda Câmara Carneiro Leão and Antônio Carlos Carneiro Leão.

Carneiro Leão married Madeleine Sathie Augustine Manuelle, a professor of French language and literature at the Faculdade Nacional de Filosofia. He took a degree in juridical and social sciences at the Faculty of Law in his native city on December 15, 1911. It should be underscored that he received the degree "[...] with distinction in all matters studied” (Niskier, 2004, p. 16). Later on, he obtained the title of Doctor of Philosophy.

Carneiro Leão's professional life was eclectic and dynamic through his multiple activities. He was notorious for the range of knowledge in all tasks he undertook ${ }^{1}$. During the period of the start and end of his bibliographic productions, between 1909 and 1964, he published conferences, discourses and studies, available in his books. Some texts may be read in Portuguese and others in English, French and Spanish.

So that his reform proposal for the teaching of foreign languages in the secondary school in Brazil could be duly investigated, it is important to describe the Brazilian context of the period, with regard to the teaching of languages and the issues involving Carneiro Leão's reform proposal.

\section{The Movement for the Reform in the Teaching of Foreign Languages in Brazil}

On November 3, 1930, at the Palácio do Catete, Getúlio Dornelles Vargas was heralded as the chief politician of the 1930 Revolution. In his inauguration speech as chief of the Provisional Government (19301934), Vargas exalted the Revolution as the result of the efforts of a new nation under construction through circumstances that favored the victory on his opponents.

The revolutionary movement, started victoriously on October 3, in the south, center and north of Brazil, and triumphant on the $24^{\text {th }}$ in this capital city, was the most positive stance we have had of our existence as a nation. No other similar event is similar to this one in all our political history. The event is really the live and vibrating expression of the will of the Brazilian people, lord of its destiny and supreme decider of its collective aims. The Revolution thoroughly warded off the exclusivity of certain classes. Civilians did not vanquish the Armed Forces. The Armed Forces did not impose their will on the former. All social 
categories, top to bottom, without any difference in age or gender, shared an identical brotherly and dominating thought: the construction of a New Fatherland, welcoming big and small, and open to the collaboration of its sons and daughters (Vargas, 2009, p. 51).

The Vargas Era or Getulist period began. It was inaugurated after the 1929 super production crisis and the 1930 Revolt "[...] as a robust movement of position-taking” (Lourenço Filho, 1944, p. 13). Vargas's inauguration as Brazil's chief politician heralded projects developed during his administration for the establishment of a teaching system that foregrounded the country's educational needs, underscoring the study of foreign languages and triggering the administration to inaugurate new plans and strategies that would make education undergo a deep reform.

According to Carneiro Leão (1935), the study of foreign languages in secondary schools "[...] has always been a weak point in Brazilian secondary education” (Carneiro Leão, 1935, p. 17). Consequently, the study of foreign languages would be wholly restructured with regard to the method in the teaching of foreign languages (English, French and German) during the Vargas administration. Further, the centralization of the Vargas provisional government was imposednot only on the economic plane but also on the political one, as soon as he took the oath of office. The 1930 regional oligarchies wanted the reconstruction of the Brazilian State within traditional modes with which they were accustomed to in governing the country.

"Army lieutenants opposed the traditional mode and supported Vargas in his proposal to reinforce central government" (Fausto, 2012, p. 283). According to Neto (2013), Vargas's first measures on his inauguration comprised the suspension of the 1891 Republican Constitution, closing of Parliament, State Assemblies and Municipal Town Halls, and the nomination of military personnel to head state governments.

Since its inauguration, the Vargas administration was greatly concerned with the country's educational system. Education was perceived as a sign of modernity in Brazil. In other words, education mainly aimed at "[...] the training of a wider and intellectually more prepared elite population” (Fausto, 2012, p. 287) for the formation of an ideal foregrounded on and imitating European and USA development.

The consolidation feeling of national identity was based on the idea that "[...] the elite population should be prepared to guide the rest of the people towards development and industrialization" (Picanço, 2003 , p. 29), or rather, towards modernity. However, so that the above could be achieved within the social relationships of the period, education would be transformed and directed towards the formation of the people, preparing them to cope with the needs of a series of activities resulting from a national reorganization.

Actually, Brazil needs a new spirit, capable of shaking the life of the nation, waking it up to the contemporary 
world. In spite of the reigning vices, a new wind of innovation is fortunately blowing. Our greatness will come from this direction. When we observe our own lives, investigatingthe nation's development, understanding our needs, facing directly our defects and working with eyes fixed on the future of our country and not on our interests and stances, we will build a strong, noble and respected nation. Brazil needs culture. Physical, mental, technical, professional, civic, social and political culture. Let's work (Carneiro Leão, 1924, p. 33).

Consequently, a government department was required that would administer the projects, plans and targets for education in Brazil. Decree 19.402, published on the 14th November 1930 (Brasil, 1930), established the Ministry of Education and Public Health and the Education Secretariats in the states. In 1931, the National Council for Education (NCE) was established, renamed Ministry of Education in 1953.

The NCE was established by Decree 19.850, published on April 11, 1931 (Brasil, 1931a). Brazil started a significant reform in its educational system, including the study of foreign languages, when the Ministry of Education and Health, the State Education Secretariats and the NCE were inaugurated. One may never know when precisely reform on the teaching of foreign languages or secondary education started. According to Chagas (1967, p. 103), "[...] the evolution in the teaching of foreign languages in Brazil is mixed up with the history of the Brazilian secondary school", or rather, the first is contained in the second, with the integration of the whole.

Due to the establishment of the Ministry of Education in 1930, secondary education would undergo an important renovation in which such qualities as activity and dynamism would be developed, strengthening people's education for all sectors of activity within society.

\begin{abstract}
If one wants to live within the present moment, education in the secondary school should be organized in such a manner that people, through a change in their milieu, may prepare themselves to reconstruct their own experience. In other words, they should adapt themselves to the new conditions of life through general culture and the growth of their personality (Carneiro Leão, 1936, p. 22).
\end{abstract}

In 1931, the Brazilian educational system would undergo a reform, known in history as the Francisco Campos Reform, aiming at transforming "[...] secondary schooling from the chaos and disrepute in which it lies" (Chagas, 1967, p. 109). The six laws that foregrounded the reform by Campos during the Vargas administration will be given below.

Francisco Campos, the minister of Education and Public Health, was "[...] a law notable of great competence. A scholar in Law, he had a formidable knowledge on the main principles of Brazilian and International Law" (Garcia, 2002, p. 3). In his discourse to justify the reform principles in secondary teaching in Brazil, Francisco Campos under- 
scored the aim of the new study plan with regard to secondary schooling as an educational stance in human formation.

\begin{abstract}
Within the meanderings of our education system, secondary education is precisely the most important not merely from the quantitative point of view, but from the qualitative aspect. It is aimed at a greater number of people and it exerts its influence on the formation of basic qualities in intelligence, judgment and character during the most relevant phase in physical and mental growth. Secondary schools aim at something wider than that which is normally attributed to them. As a rule, secondary schooling has always been considered a simple step for young people's preparation to higher education. Consequently, its educational function is discarded. This boils down to discarding of the development of the faculties of appreciation, judgment and criterion, basic in all human activities, particularly in the formation and training of the intelligence in problems within their precise terms and seeking the most adequate solutions (Campos, 1940, p. 45).
\end{abstract}

So that concern with people's formation would be foregrounded, according to Decree 20.158 of June 30, 1931 (Brasil, 1932a), secondary education established a serial curriculum, compulsory attendance at school, the need for a secondary school certificate for those who intended to enter institutions of higher education, and a two-cycle teaching. Secondary education in Brazil was organized in two cycles: a 5-year basic course and a 2-year complementary course and a 3-year commercial course. Secondary schooling lasted 7 years, or rather, five years in the basic course and two years in the complementary one (a preparatory course to enter higher education). Students, who intended to devote themselves to juridical studies, were trainedin the Humanities during the final two years, whilst the student who intended to study Medicine, Pharmacy and Dentistry had a formation devoted to the natural sciences. Students who intended to enter an Engineering or Architecture course had further studies in Mathematics.

The teacher-in-chief was a prominent person in the current reform. His function was not merely the supervision and guidance of teachers with regard to teaching, but also a school administrator. The teacher-in-chief was simultaneously "[...] a head of department [...] and a teacher who monitored his assistant teachers" (Fonseca, 1997, p. 101), in charge of his subordinates and of teaching. As teacher-in-chief of the French language, Carneiro Leão "[...] guided and supervised forty teachers" (Mendonça, 1997, p. 12) in the reform of foreign languages at secondary level. Besides giving lessons for the third and fourth years, he supervised "[...] the methodology employed, considered at that time a revolution in the teaching of languages" (Mendonça, 1997, p. 12).

Carneiro Leão $(1934$, p. 7) states that the Colégio D. Pedro II comprises two segments: "[...] a day school with more than two thousand students and a boarding school with more than four hundred students". A headmaster, a supervisor of French, English and German, and other 
assistant teachers for teaching language in their respective classes were present in both segments.

Assistant teachers were those in charge of teaching the language concerned and the supervisors were in charge of supervising the assistant teachers during the first two years. The headmasters not only supervised assistant teachers but were also commissioned to teach the language for fourth- and fifth-year students. The single paragraph of Article 1 of the Reform Instruction was clear with regard to the tasks of assistant teachers and headmasters.

\begin{abstract}
$\$ 1$ - During the first years, the teaching of languages will be the task of Assistant teachers; during the last years, the headmaster of each language has the task of giving lessons to students of the last two years of both premises; the latter also have the task of guiding and monitoring the assistant teachers (Brasil, 1932c, p. 4.240).
\end{abstract}

Either because of demise, retirement and transference, the Colégio Dom Pedro II did not have any full professor of foreign languages. Moreover, the first article of Decree 20.833, published on December 21, 1931 (Brasil, 1931b) extinguished the position of full professor of French, English and German of the day and boarding schools of the Colégio Dom Pedro II.

In Carneiro Leão's opinion (1934, p. 7), timing was conducive for "[...] the experience of a radical reform" in the teaching of foreign languages in the secondary school. The federal government itself would take the reform in its hands. Delgado de Carvalho, headmaster of the day school, endorsed the reform that minister Francisco Campos implemented within the official secondary schools. However, prior to the application of the reform, Delgado de Carvalho retired from the Colégio Dom Pedro II, but his successor, Henrique de Toledo Dodsworth made it a point to materialize the reform plan. He formed a commission to organize the minutes of the foreign language reform, with its implementation on the $27^{\text {th }}$ February 1932.

On the 28th November, Dr. Delgado de Carvalho quitted the headmastership of the day school and became its deputy headmaster. In the meantime, Dr. Delgado de Carvalho became headmaster during a highly active period, namely, the exams period prolonged till the opening of lessons with partial exams and external candidates subjected to exams before the teachers of the Colégio Dom Pedro II. He was characterized by work, reflecting the activity of his August Patron, within the functions of the semi-secular performance in the office of the first magistrate of the Nations faithful to 'nulla dies sine labor' (Doria, 1937, p. 244, author's italics).

The commission, composed of teachers Delgado de Carvalho, Adrien Delpech, Antenor Nascentes, Julio Nogueira, Oswaldo Serpa and Carneiro Leão, discussed for days a memorandum that would organize the teaching of French and other foreign languages in the Colégio D. 
Pedro II. The memorandum was the Working Order of Decree 20.833 published on December 21, 1931 (Brasil, 1932b).

[...] The teaching of live foreign languages in the Colégio Dom Pedro II by the Direct Method, [...] lacks a working policy. It was formulated by teachers Antenor Nascentes, Adriano Delpech, Delgado de Carvalho, Oswaldo Serpa, Julio Nogueira and Dr Antonio Carneiro Leão, headmaster in the teaching of French, and approved by the Ministry of Education and Public Health. A working policy was prepared for the direct teaching of French, English and German at the Colégio Dom Pedro II (Doria, 1937, p. 249).

The working policy was elaborated from Decree 20.833 published on December 21, 1931 (Brasil, 1931b) to execute the foreign language reform. It was published in the Government Gazette of Rio de Janeiro on March 9, 1932.

The reform's working policy (Brasil, 1932b) proposed that the teaching of foreign languages should be practical and given in the language concerned. The most important disseminator for the direct implantation of the method through the reform of foreign languages in the secondary school was "[...] the teacher-in-chief in French of the Colégio D. Pedro II, A. Carneiro Leão” (Chagas, 1967, p. 111).

Carneiro Leão perceived the possibility of the reform of foreign languages in Brazil in so far as the discipline in the secondary school curriculum would comply with the real needs of the country during the 1930s. Consequently, he developed several items for the reform of teaching foreign languages in secondary schools. Table 1 demonstrates these activities.

\section{Table 1 - Items suggested by Carneiro Leão in the Foreign Language Reform (1930-1934)}

\begin{tabular}{l}
\hline 1. study load in foreign languages; \\
\hline $\begin{array}{l}\text { 2. formation of new classes to decrease the number of students in the } \\
\text { classroom, per discipline (French, English and German) so that the assistant } \\
\text { teacher may have better teaching control; }\end{array}$ \\
\hline 3. hiring of new teachers to gives lessons in foreign languages; \\
\hline 4. a chat club to practice language orality; \\
\hline $\begin{array}{l}\text { 5. Correspondence exchanges by students of French with French secondary } \\
\text { school students; }\end{array}$ \\
\hline 6. the use of language laboratories; \\
\hline 7. the use of disks and the radio in the teaching of foreign languages; \\
\hline $\begin{array}{l}\text { 8. preparation of didactic material that would comply with the aims of the } \\
\text { new teaching; }\end{array}$ \\
\hline $\begin{array}{l}\text { 9. the implantation of the direct method (new method) which provided } \\
\text { the study of foreign languages to the curriculum of the secondary school } \\
\text { (French, English and German) through a more practical and dynamic } \\
\text { process in which the language is perceived as a living vehicle, with a priority } \\
\text { on vocabulary and day to day issues in the development of the students } \\
\text { linguistic education. }\end{array}$
\end{tabular}

Source: Authors, adapted from Chaguri (2017).

8 Educação \& Realidade, Porto Alegre, v. 44, n. 4, e87897, 2019. 
The items developed by the foreign language reform, at first restricted to the Colégio D. Pedro II and afterwards extended to other schools, revealed that the main targets that foregrounded teaching in the 1930s were reading, speaking, understanding and writing. As a rule, they were the aims specified for the language courses in secondary schools.

In the text written to fill a vacancy for the seventh chair in the Institute of Education of São Paulo, José Rodrigues de Arruda, teacher-inchief of the first educational section of the Normal School of Itapetininga, called attention to current changes and the requirements in the education of secondary school students due to the new social scenario implanted in Brazil in the 1930.

\begin{abstract}
The new established social order and the facility in transmitting one's thoughts make mandatory the learning of foreign languages. The need, established by contemporary man, is in itself a precious source of motivation and interest for learning. On the one hand, there is the search for employment, positions in companies and commerce. On the other hand, the curiosity of knowing peoples which continually influences our life rhythm (Arruda, 1938, p. 106).
\end{abstract}

The main issue was to transform not merely the teaching of foreign languages into dynamic and conscious activities but also the teaching of other subject matters, such as Mathematics, Physics, Chemistry and the Natural Sciences. Teaching would be based on the new social order fomented by the market that dominated the country, thus conducting a learning directing towards its needs. Consequently, changes from the traditional (grammar and translation) into the modern method (direct method) heralded the quality of usefulness in the study of foreign languages at secondary school level.

The direct method started to be employed in the early 20th century as a contrast to the classical one. It was actually a response to the manner of establishing the new social needs of the period. The method became extremely popular during the first half of the $20^{\text {th }}$ century.

According to Richards and Rodgers (1994), the teaching reform in foreign languages in the UK at the end of the 19th century imploded the supremacy of the classical method. Led by Henry Sweet, the reform forwarded a kind of teaching that gave priority to students to communicate in the target language they were studying. The direct method was forwarded by Lambert Sauveur (1826-1907) in the USA, in 1874, for the teaching of foreign languages. In fact, he was a pioneer in the direct method on the American continent immediately after the British reform.

Richards and Rodgers (1994) underscore that the direct method was first introduced in Europe and later in the US by Maximilian Berlitz. The Berlitz method, widely disseminated by the Berlitz Language Schools, was taught in schools throughout the world and is still active today. The principle of the direct method consists in "[...] students 
learning how to communicate in the target language" (Larsen-Freeman, 2008, p. 28). Their success lies in thinking in the language they are studying.

Rather than using analytical procedures that focus on explanation of grammar rules in classroom teaching, teachers must encourage direct and spontaneous use of the foreign language in the classroom. Learners would then be able to induce rules of grammar (Richards; Rodgers, 1994, p. 9).

Teaching technique in the method is established by direct contact between meaning and words in the target language where three pedagogical implications should be taken into account. The first is associated with the prohibition of using the mother's tongue by the teacher and by the student in foreign language classes. Only the foreign language studied in the classroom should be employed. The second principle is the prohibition of translating in the classroom and the third is related to fluency of the target language teacher so that the direct method would be employed in the classroom.

If for any motive the student does not know the meaning of a word, the teacher should employ certain mechanisms to be understood and the student would assimilate the explanation. He should therefore be able to create strategies that would help him in the translation of a particular word or any other doubt in the target language. Gestures, images, pictures and other objects are tools that teachers may employ when they are teaching a foreign language by the direct method. One should remember that the mother tongue is forbidden in the classroom. This is the reason why Art. 4 of the Working Policy of the Reform indicates that the teaching of foreign languages in the Colégio D. Pedro II should be "[...] given through tables, books and other material that trigger subjects for dialogue” (Brasil, 1932c, p. 4.240) between students and teachers.

Consequently, when one thinks of a type of teaching based on utilitarian parameters, one may not remove from the curriculum any component to guarantee the theoretical and practical study of the other disciplines, as the case in foreign languages. It should be underscored that the defense of utilitarian teaching of foreign languages is not a new thing. As may be seen soon, the utilitarian issue in the study of curricular components, with other ends in view, was a great concern in the $17^{\text {th }}$ century. However, in the $19^{\text {th }}$ century, concern on a utilitarian study was still debated among education professionals. This statement may be perceived in the doctoral thesis of Oliveira (2006) who revealed that, in a 1884 report, the general inspector of the Colégio D. Pedro II, Antonio Herculano de Souza Bandeira Filho, met the school congregation during thirteen times, during 1883, to discuss the organization of the teaching of Philosophy. However "[...] in several sessions, the board dealt with the study of foreign languages” (Oliveira, 2006, p. 177).

According to Oliveira (2006), the inspector-general's report reveals that teachers of foreign languages in the Colégio D. Pedro II gave 
their written opinion on the teaching methodology employed. All opinions were submitted to a committee which, in its turn, produced eight conclusions on the teaching of foreign languages.

The first conclusion indicated that it was highly convenient to conserve the study of the Vernacular Language, divided into three courses, established by current rules, to make easy the learning of other Languages, besides being indispensable. [...] The second conclusion said that Living Languages should be taught in such a manner that works written in those languages could be understood. Consequently, the study of these languages should start in the first years of the course, [...] to acquire a good pronunciation. [...] The above measure, according to the third conclusion, should not restrict the teaching of Living Languages to the lower classes, but to make students better equipped to sit for the Final Exams in the seventh year. [...] The fourth conclusion established the progression of Living Language: when students were proficient in Latin and French, [...] they would be ready to start practicing ${ }^{2}$ English and, afterwards, German. The fifth conclusion said that in the fourth year of Latin, the students should start studying Greek, with experience on the greatest number of prose writers and poets [...]. With regard to the grammar of any of these languages, its definitions, divisions and classifications, they should, as far as possible, be unified and simplified, since complications would confound the spirit of the young people (Conclusion 6). Each teacher should choose the method which seemed best (Conclusion 7), in so far as it did not discard the current rules with 'grammatical petty details' or oblige the students with Themes and extremely extensive translations. [...] The eighth conclusion was not to be 'effective' with non-regular students ${ }^{3}$, at least, within the duration of the 'bad disposition' of Article 14 of the current regulations, which should be changed so that the preliminary exam for the Entrance Examination would be allowed in any year for any language, in the Day or Boarding School (Oliveira, 2006, p. 277-278).

During the $19^{\text {th }}$ century, the schedule in the teaching of languages in the Colégio D. Pedro II comprised the study of the classics (Latin and Greek) and Living Languages (French, English and German). According to Oliveira (2006, p. 287), the teaching of living languages "[...] should be the most practical to make the student speak and write correctly in foreign languages, with the teacher trying to familiarize the students with the best writers of the different languages.

However, even though the practical tone within the study of foreign languages was underscored, there was no methodological distinction for the teaching of the classics and any other foreign language. Oliveira (2006) highlights that the seventh conclusion of the language teachers gave freedom to the teacher to adopt any method in language learning. 
In the $20^{\text {th }}$ century, however, the study program in the Colégio D. Pedro II and in the other schools that followed the same pedagogical plan was revised. In other words, Carneiro Leão was responsible for changing the method for the study of foreign languages. From the methodological point of view, Carneiro Leão $(1934 ; 1935)$ innovated the teaching of foreign languages when he proposed a type of teaching that made adequate contemporaneity to the valorization of usage which foreign languages represented in the relevant growth of secondary schools through the Francisco Campos's reform.

Gradually, the concept of the literary, or rather "[...] the genius of foreign writers, was transformed into utilitarianism" (Carvalho, 1940, p. 320) for the study of foreign languages by the new study curriculum of secondary schools.

Carneiro Leão freed the systematic study of grammar rules, inherited from the methodology in the teaching of classical languages, from the classic method, and tried to make feasible a greater formatting in the natural use of modern languages (French, English and German) through the direct study of the language, without recurring to the exercises of artificial rules.

It should be underscored that, in the case of the Colégio D. Pedro II, the aim for this new organization in the study of foreign languages, as insisted upon by Carneiro Leão (1934), was to foment speaking and writing in foreign languages and, gradually, to lead him towards the study of "[...] literature, preparing the student to be sensitive to the language of good writers" (Carneiro Leão, 1934, p. 21).

The new program for language studies kept "[...] a balance between the extremes of Science and Languages, between the classic and the modern, between humanism and technology" (Chagas, 1967, p. 109-110) in students'formation. The above kept a fine-tuning with the principles of Francisco Campos's reform, or rather, to provide the study plan of the secondary school with "[...] a literary education, a scientific education or a technical education” (Teixeira, 1956, p. 78).

Carneiro Leão did not want to abandon the study of the classics but he wanted to take advantage of the moment and, through the new method, review the study of foreign languages in Brazil "[...] through direct and immediate contact with people of a country with those of another" (Carneiro Leão, 1935, p. 26), establishing the need to speak foreign languages because of increasing internationalization of capital in the world.

Since the 1930, Brazil underwent upheavals in its economic and social profile. Changes were based on industrialization and, without any doubt, by replacing the labor of immigrants in the great urban centers such as São Paulo and Rio de Janeiro. The arrival of workers from other regions of the country, for example, the northeastern region, was conspicuous for their predominance in the economically more dynamic regions of the country. 
During the period under analysis, Brazil was experiencing a significant industrial growth and an important phase in the country's economy was being inaugurated. Brazil was quitting being an exporter of grains and was transforming itself into a country with large-scale industrial activities. Education became "[...] not merely a tool for the cultured elite but a process of real preparation for the different modalities of modern life" (Teixeira, 1976, p. 25).

In other words, "[...] education was inserted within a general centralizing focus" (Fausto, 2012, p. 288) for the implantation of an active, living and dynamic school to attend to people's needs within this new social order. Francisco Campos's reform was “[...] the first real attempt [...] to update the study of modern languages" (Chagas, 1967, p. 110) at secondary level.

The introduction of the same program for the study of modern languages in the Colégio D. Pedro II and in other secondary schools and the main aims for the teaching of languages were based on three principles. Table 2 demonstrates these principles and their aims.

Table 2 - Principles for the teaching of the Curricular Program for Foreign Languages in the Colégio D. Pedro II

\begin{tabular}{|c|l|}
\hline $\begin{array}{c}\text { TEACHING } \\
\text { PRINCIPLES }\end{array}$ & \multicolumn{1}{c|}{ AIMS } \\
\hline Instrumental & $\begin{array}{l}\text { 1. to read and understand, with ease and for pleasure. } \\
\text { 3. to understand a foreign language when spoken. } \\
\text { 4. to write with relative exactness }\end{array}$ \\
\hline Cultural & $\begin{array}{l}\text { 1. to know the civilization of the people whose language one is } \\
\text { studying. } \\
\text { 2. to appreciate the literary and artistic meaning of the foreign } \\
\text { language. }\end{array}$ \\
\hline Educational & $\begin{array}{l}\text { 1. to develop habits for comprehension and use of more efficient } \\
\text { processes for the penetration of the foreign language. } \\
\text { 2. to adopt the attitude to understand the ideals and traditions of } \\
\text { foreign peoples. } \\
\text { 3. havingleisure time for reading in a foreign language. }\end{array}$ \\
\hline
\end{tabular}

Source: Based on Junqueira Schmidt (1935).

The main aims that foreground the teaching of foreign languages in Brazilian secondary schools are multiplied in the three specific ends and make possible the achievement of the direct method among those "[...] who devote themselves to the teaching of languages" (Junqueira Schmidt, 1935, p. 13). Since the 1930s, the status of foreign languages was on the rise, together with the different spheres that made up the social order of the day.

The status of the modern language was evidently born according to the number of intellectual, industrial, commercial interchanges of contemporary people, intensified through the competition of mechanical means. The ra- 
dio, the cinema, voyages and the fast development of the press provided great resources of communion in human thought (Arruda, 1938, p. 106).

When he perceived these changes in the country's social scenario, Carneiro Leão (1932) tried to apply a new method for the teaching of languages in the secondary schoolwithin the educational milieu. He tried to demonstrate that experience should not be solely identified with practical occupations, with material interests and certainly not making it the unique mode of knowledge. Experience should be understood by intelligence that makes it an educating factor. Experience is made up of “[...] physical stimuli" (Carneiro Leão, 1932, p. 293) which present an educational characteristic when interpreted by knowledge. The above statement may be understood through Locke's philosophy. In fact, Carneiro Leão employed the ideas of the English philosopher to foreground his reasoning.

[...] Some three centuries ago, Locke defined that there are two processes in knowledge: an external one made up of feelings, the product of observation and experience; the external one is the product of reflection. Man knows through experience interpreted by intelligence. Experience works according to the end that one wants to achieve. Experience will be perceived one way or another according to the aim of obtaining ideas tending towards a social attitude of culture or towards a technical capacity aimed at achieving a new aptitude for the struggle towards a determined position in the community (Carneiro Leão, 1932, p. 293).

Carneiro Leão is making clear that experience should not be characterized primarily as education, as knowledge. It should be highlighted that experience exerts an educational value when the conclusion (logic; deduction) of educational practices is removed, providing the primacy of knowledge over life. The employment of the direct method in the teaching of modern languages would make secondary students grow, develop, improve, refine themselves and, added to the other areas of knowledge, provide the opportunity to live and govern their social and human behavior.

Therefore, the principles for the teaching of foreign languages should be directed not only to practical teaching but also to scientific and intellectual teaching, aligned to the utilitarian and intellectual culture where "[...] they mix and, served by the sciences" (Carneiro Leão, 1932, p. 295), combine to form their full identity.

The study of language and literature in foreign languagelessons is directed neither towards a solely classical and a low scientific formation, but necessarily for useful ends. The scientific and classic characteristics of the study of languages and their literature are useful as a modernizing element for human education.

The education of the new type of population in the 1930s should be complete. The new social order requires people ready to attend to 
industrial and commercial development. In other words, the new population should be able to relate itself to others of different habits, beliefs and values.

So that education would attend to the dictates of this new order for the study of languages, it has to be contrary to a type of teaching based on the memorization of grammar rules and in the numberless words to be learned by heart and de-contextualized in the acquisition of the new language. The great opposition that Carneiro Leão believed to be the watershed for the reformation of foreign languages in secondary schools was based on the pedagogical thought of the philosopher and educator John Locke.

According to Locke (1889), all knowledge comes from one's perception of feelings and experimentation, or rather, from perception of intelligence. Locke insisted that the teaching of a language is to transmit the notion of its practical use, whose formation "[...] follows the popular use of words" (Locke, 1889, p. 115) and never artificial rules.

The direct method proposed by Carneiro Leão to reform the teaching of foreign languages at secondary school level exceeded the model of the traditional school which highlighted teaching of a bookish type, or rather, memorization techniques and concepts without any concern for functionality of the activities developed for the study of the language.

The method provided the foreign language course in secondary schools with a new rhythm. In fact, it directed students towards social development through their insertion in the country's production mode. Changes in the methodology for the teaching of foreign languages in the Colégio D. Pedro II and other establishments were a reflection of the contradiction between the classics and the modern. They inaugurated a highly practical teaching without removing the characteristic of promoter of the Humanities that wanted to integrate people with the globalization of social relationships and thus the development of society.

Carneiro Leão's idea of education takes into account society as a harmonic whole. In The Duty of the New Brazilian Generations, Carneiro Leão (1923) perceives the human being in two ways: (1) the establishment of collective well-being and (2) social development. According to Carneiro Leão (1923), equilibrium as a social factor to the society of his era was needed to develop culture in a universal manner. Research by Lima (2011), Silva (2006), Schelbauer and Machado (2013) denote this educational characteristic in Carneiro Leão's works.

Further, through the development of culture, experiences that were lacking in individuals (experience is culture) could be disseminated through events, press, debates, conferences and seminars. However, according to Azevedo (1971), access to culture was lacking in $20^{\text {th }}$ century Brazilian society. Moreover, since culture was a basic theme for the development of the country (Carneiro Leão, 1917), Brazil had to activate new strategies to have the greatly expected progress, as Carneiro Leão wished. 
His works are characterized by the very nature of practical studies. His concern on foreign languages may be understood in the wake of industrialization and urbanism with growing success in Brazil. Allied to Europe and the USA, Brazil wanted to reformulate its concept of education to prepare the new man for productive activities. Man could not be limited to a literary culture, but to work. In his book Brazil and Popular Education, Carneiro Leão underscored the need for valorizing labor for the new man.

In our country, the cultivation of the soil, until recently executed by slaves, had neither the arms that were freed and hated the old profession nor those of free men who with difficulty could replace the slave! The crisis was tragic. To heal it, time and practical and utilitarian education were needed for the glory of modern man (Carneiro Leão, 1917, p. 23).

There was a need for an educational plan that would attend to the requirements of intellectual, moral, civic, hygiene and physical education that would prepare the Brazilian people for citizenship and for a useful and productive life. There was a need for a linguistic education that would provide the study of foreign languages with a new and modern method capable of leading Brazilian students to "[...] speak and write, and thus, culture" (Carneiro Leão, 1935, p. 18). This was the utilitarian education conceived by Carneiro Leão for education in Brazil, without disregarding the promotion of the Humanities which integrated people with the globalization of social relationships.

In 1909, he published Education (Carneiro Leão, 1909), the result of a conference given at the First Students' Brazilian Conference at the Faculty of Law in Recife. The text shows his concern on the development of society, since the theme provoked in-depth discussions on criminality in the Law undergraduate course. In fact, criminality was the result of a lack of social development and collective well-being in $20^{\text {th }}$ century Brazilian society.

Based on the utilitarian characteristic, without disregarding the promotion of the Humanities, education conceived by Carneiro Leão should attend to the requirements of the new industrial and urban society. Education would correct social distortions of the period "[...] by neutralizing the harmful and shameful load from our ethnic roots" (Araújo, 2002, p. 119). Only a type of education, practical and useful to the proposal of current age, would change the country's waywardness.

\section{Conclusion}

Education experienced its historical hour during the 1930s. A new phase began and would change the directions of Brazil. It comprised the establishment of the Ministry of Education and Public Health (current MEC). Francisco Campos, the new minister of Education and Health, inaugurated the National Council of Education to organize and structure education at all levels. The reform of the Secondary School, 
also called the Francisco Campos Reform, started in Brazil on April 18, 1931, aimed at preparing the population of the city for higher education by giving it a technical and practical formation to reach all segments of society.

Antônio Carneiro Leão enhanced a dynamic and active teaching of foreign languages. All activities throughout the reform, such as study load in languages, the formation of new groups, the hiring of new teachers, the establishment of chats for the practice of orality, exchange with French student groups, language laboratories, the uses of disks and the radio in language classes, the preparation of didactic material and the new direct method, would prepare city and town populations for their insertions in production activities. The country would thus achieve full industrialization and urbanization in the great cities such as Rio de Janeiro and São Paulo.

The reform of foreign language teaching conceived by Carneiro Leão implied a balance between the Humanities and the Sciencesin the formation of students so that they could attend to the needs of the country's trend towards industrialization. Carneiro Leão proposed utilitarian knowledge. Although the Humanities composed the curriculum, both were required for people's formation. One could not discard Science since it triggered progress. One could not discard the Humanities since they united populations. The solution was the use of the method as a solution. The direct method was the most appropriate way to combine knowledge and give people a utilitarian formation.

The reform of foreign language teaching by Carneiro Leão allowed the mandatory stance for the study of a foreign language in the curriculum of basic and secondary education. Carneiro Leão's debates were updated due to the comprehension we have of the past with regard to the present. Many items that Carneiro Leão "[...] thought of in the early 20th century have still to materialize today" (Niskier, 2004, online). Portugal, Spain, UK and Ireland include more than one foreign language in their curricula. Brazil is still unaware of plurilinguism and produces ideological concepts constructed on monolinguistic education. This is due to the compulsory study of only one foreign language, English or Spanish (Mercosur) in the curriculum of Brazilian schools.

Received on November 02, 2018 Approved on May 27, 2019

\section{Notes}

1 Chaguri and Machado (2018) provide a biographical note on Carneiro Leão, where the reader may have important information on his private and professional life and his connections with other Brazilian politicians.

2 The Portuguese term used tirocinio refers to learning and/or experience acquired in the exercise of several activities.

3 Some students were enrolled in single subjects and they had to sit for exams so that they could become regular students.

Educação \& Realidade, Porto Alegre, v. 44, n. 4, e87897, 2019. 


\section{References}

ARAÚJO, Cristina. A Escola Nova em Pernambuco: educação e modernidade. Recife: Fundação de Cultura, 2002.

ARRUDA, José Rodrigues de. Da Aprendizagem das Línguas Vivas e Mortas. Piracicaba: Tip. Do Jornal de Piracicaba: 1938.

AZEVEDO, Fernando de. A Cultura Brasileira. 5. ed. São Paulo: Melhoramentos/ Editora da USP, 1971.

BRASIL. Ministério da Educação, Cultura e Saúde. Decreto no 19.402, em 14 de novembro de 1930. Cria uma Secretária de Estado com a denonimação de Ministério dos Negócios da Educação e Saude Publica. Diário Oficial da União, Rio de Janeiro, 18 nov. 1930.

BRASIL. Ministério da Educação, Cultura e Saúde. Decreto no 19.850, de 11 de abril de 1931. Crêa o Conselho Nacional de Educação. Diário Oficial da União, Rio de Janeiro, 15 abr. 1931a.

BRASIL. Ministério da Educação, Cultura e Saúde. Decreto no 20.833, de 21 de dezembro de 1931. Diário Oficial, Rio de Janeiro, 24 dez. 1931b. Available at: <http://www2.camara.leg.br/legin/fed/decret/1930-1939/decreto20833-21-dezembro-1931-508467-publicacaooriginal-1-pe.html>. Accessed on: Aug. 12, 2015.

BRASIL. Ministério da Educação, Cultura e Saúde. Decreto no 20.158, de 30 de junho de 1931. Organiza o ensino comercial, regulamenta a profissão de contador e dá outras providências. Diário Oficial da União, Rio de Janeiro, 13 fev. 1932a.

BRASIL. Ministério da Educação, Cultura e Saúde. Instrução para Execução do Decreto no 20.833, de 21 de dezembro de 1931. Diário Oficial, Rio de Janeiro, 9 mar. 1932b. Available at: <http://www.jusbrasil.com.br/diarios/1997679/pg8-secao-1-diario-oficial-da-uniao-dou-de-09-03-1932>. Accessed on: Aug. 10, 2015.

BRASIL. Ministério da Justiça. Regularia as Normas para o Trabalho. Decreto no 21.186, de 22 de março de 1932. Diário Oficial, Rio de Janeiro, 31 mar. 1932c. Available at: <http://www2.camara.leg.br/legin/fed/decret/1930-1939/decreto21186-22-marco-1932-524876-publicacaooriginal-1-pe.html>. Accessed on: Apr. 04, 2016.

CÂMARA, Sônia. As Reformas de Instrução Pública e a Educação Profissional Feminina do Distrito Federal durante os Anos 20. In: MAGALDI, Ana Maria. ALVES, Cláudia. GONDRA, José Gonçalves (Org.). Educação no Brasil: história, cultura e política. Bragança Paulista: EDUSP, 2003. P. 399- 417

CAMPOS, Francisco. Educação e Cultura. Rio de Janeiro: José Olympio Editora, 1940. [1930].

CARNEIRO LEÃO, Antônio. Educação. Recife: Imprensa Industrial, 1909.

CARNEIRO LEÃO, Antônio. O Brasil e a Educação Popular. Rio de Janeiro: Tip. Jornal de Comércio, 1917.

CARNEIRO LEÃO, Antônio. Os Deveres das Novas Gerações Brasileiras. Rio de Janeiro: Sociedade de Propriedade dos Países Americanos, 1923.

CARNEIRO LEÃO, Antônio. Os Deveres das Novas Gerações. In: CARDOSO, Vicente Licínio (Org.). À Margem da História da República. Rio de Janeiro: Annuario do Brasil, 1924. P. 17-33. 
CARNEIRO LEÃO, Antônio. O Problema do Método. Boletim de Educação Pública, Rio de Janeiro, v. 2, n. 3, p. 291-298, 1932.

CARNEIRO LEÃO, Antônio. O Ensino das Línguas Vivas: uma experiência brasileira. Rio de Janeiro: Serviço de Publicações do Instituto de Pesquisas, 1934.

CARNEIRO LEÃO, Antônio. O Ensino das Línguas Vivas: seu valor, sua orientação científica. São Paulo: Companhia Nacional, 1935.

CARNEIRO LEÃO, Antônio. Tendências e Diretrizes da Escola Secundária: aspectos da sociologia educacional. Rio de Janeiro: Typ. Jornal do Commercio, 1936.

CARVALHO, Carlos Delgado de. Sociologia Educacional. 2. ed. São Paulo: Companhia Editora Nacional, 1940.

CHAGAS, Raimundo Valnir Cavalcante. Didática Especial de Línguas Modernas. 2. ed. São Paulo: Editora Nacional, 1967.

CHAGURI, Jonathas de Paula; MACHADO, Maria Cristina Gomes. Guia de Fontes da Bibliografia de e sobre Carneiro Leão. Uberlândia: Navegando Publicações, 2017. Available at: <https://www.editoranavegando.com/>. Accessed on: Oct. 31, 2017.

CHAGURI, Jonathas de Paula; MACHADO, Maria Cristina Gomes. Notas Biográficas de um Educador Brasileiro: Antônio Carneiro Leão. REVELLI - Revista de Educação, Língua e Literatura, Inhumas, v. 10, n. 1, p. 70-98, 2018.

CHAGURI, Jonathas de Paula. Antônio Carneiro Leão e a Reforma das Línguas Estrangeiras no Ensino Secundário Brasileiro (1930-1934). 2017. 338 f. Tese (Doutorado em Educação) - Universidade Estadual de Maringá, Maringá, 2017.

DORIA, Escragnolle. Memória Histórica Comemorativa do $1^{\circ}$ Centenário do Colégio de Pedro Segundo: 2 de dezembro de 1837 - 2 de dezembro de 1937. Rio de Janeiro: Ministério da Educação, Cultura e Saúde, 1937.

FAUSTO, Boris. História do Brasil. 14. ed. São Paulo: Editora da Universidade de São Paulo, 2012.

FONSECA, Selva Guimarães. Ser Professor no Brasil: história oral de vida. 3. ed. Campinas: Papirus, 1997.

GARCIA, Nelson Jahar. Apresentação. In: CAMPOS, Francisco. O Estado Nacional. São Paulo: Ebooklibris, 2002. P. 3-5.

JUNQUEIRA SCHMIDT, Maria. O Ensino Científico das Línguas Modernas. Rio de Janeiro: Briguiet \& Cia, 1935.

LARSEN-FREEMAN, Diane. Techniques and Principles in Language Teaching. New York: Oxford University Press, 2008.

LIMA, Rosilene de. A Sociologia da Educação na Obra de Carneiro Leão e suas Contribuições na Formação de Professores. 2011. 180 f. Dissertação (Mestrado em Educação) - Universidade Estadual de Maringá, Maringá, 2011.

LIMA, Rosilene de. Carneiro Leão e a Educação Rural Brasileira: um projeto cultural, político e modernizador (1909-1963). 2016. 187 f. Tese (Doutorado em Educação) - Universidade Estadual de Maringá, Maringá, 2016.

LIMA, Rosilene de; MACHADO, Maria Cristina Gomes. Carneiro Leão: considerações acerca da sociologia educacional. Educação, Santa Maria, v. 40, n. 1, p. 143-154, 2014.

LOCKE, John. Some Thoughts Concerning Education. 2 ed. Cambridge: Cambridge University Press, 1889. 
LOURENÇO FILHO, Manuel Bergström. A Educação, Problema Nacional. Revista Brasileira de Estudos Pedagógicos, Rio de Janeiro, v. 1, n. 1, p. 7-28, 1944.

MACHADO, Maria Cristina Gomes. Carneiro Leão e a Questão da Educação Superior. Revista Brasileira de História da Educação, Campinas, n. 17, p. 103-121, 2008.

MENDONÇA, Sandra Cabral. Carneiro Leão: sonhos e frustrações na diretoria de instrução pública do Distrito Federal (1922-1926). 1997. 70 f. Dissertação (Mestrado em Educação) - Faculdade de Educação, Pontifícia Universidade Católica do Rio de Janeiro, Rio de Janeiro, 1997.

NETO, Lira. Getúlio 1930-1945: do governo provisório à ditadura do Estado Novo. São Paulo: Companhia das Letras, 2013.

NISKIER, Arnaldo. O Educador Carneiro Leão. Discurso de posse no Instituto Histórico e Geográfico de São Paulo, em 31 de outubro de 2001. Rio de Janeiro: Academia Brasileira de Letras, 2004. Available at: <http://www.academia.org. $\mathrm{br} / \mathrm{abl} / \mathrm{media} /$ prosa7a.pdf $>$. Accessed on: Jul. 15, 2015.

OLIVEIRA, Luiz Eduardo Meneses de. A Instituição do Ensino das Línguas Vivas no Brasil: o caso da língua inglesa (1809-1890). 2006. 378 f. Tese (Doutorado em Educação) - Pontifícia Universidade Católica de São Paulo, São Paulo, 2006. PAULILO, André Luiz; VIDAL, Diana Gonçalves. Projetos e Estratégias de Implementação da Escola Nova na Capital do Brasil (1922-1935). In: MAGALDI, Ana Maria; ALVES, Cláudia; GONDRA, José Gonçalves (Org.). Educação no Brasil: história, cultura e política. Bragança Paulista: EDUSF, 2003. P. 375-398.

PICANÇO, Deise Cristina de Lima. História, Memória e Ensino de Espanhol (1942-1990). Curitiba: Editora da UFPR, 2003.

RICHARDS, Jack; RODGERS, Theodore. Approaches and Methods in Language Teaching: adescription and analysis. Cambridge: Cambridge University Press, 1994.

SCHELBAUER, Analete Regina; MACHADO, Maria Cristina Gomes. Pela Educação Rural de Antônio Carneiro Leão. In: MESQUITA, Ilka Miglio de; CARVALHO, Rosana areal de. (Org.). Clássicos da Educação Brasileira. Belo Horizonte: Mazza Edições, 2013. P. 65-80.

SILVA, Josie Agatha Parilha da. Carneiro Leão e a Proposta de Organização da Educação Popular Brasileira no Início do Século XX. 2006. 131 f. Dissertação (Mestrado em Educação) - Universidade Estadual de Maringá, Maringá, 2006.

SILVA, Josie Agatha Parrilha; MACHADO, Maria Cristina Gomes. Carneiro Leão: a educação popular e a formação de professores. Série-Estudos (UCDB), Campo Grande, n. 17, p. 103-117, 2004.

TEIXEIRA, Anísio. A Educação e a Crise Brasileira. São Paulo: Companhia Editora Nacional, 1956.

TEIXEIRA, Anísio. Educação no Brasil. São Paulo: Companhia Editora Nacional, 1976.

VARGAS, Getúlio. Discurso Pronunciado por Ocasião de sua Posse como Chefe do Governo Provisório da República. In: BRASIL. Ministério das Relações Exteriores. Discursos Selecionados do Presidente Getúlio Vargas. Brasília: FUNAG, 2009. [1930]. P. 51-55. 
Jonathas de Paula Chaguri has a Ph.D. in Education. He participates in the Research and Studies Group History of Education, Intellectuals and School Institutions (GEPHEIINSE) registered in the research groups directory of CNPq. He is Adjunct Professor at the Pernambuco University (UPE - Campus Mata Norte), Recife, Brazil, working in the Education course.

ORCID: http://orcid.org/0000-0002-7525-9653

E-mail: jonathas.chaguri@upe.br

Maria Cristina Gomes Machado has a Ph.D. in Philosophy and History of Education. She performed a post-doctoral internship at the Federal University Federal of Minas Gerais in the area of Education. She is currently a Full Professor at the State University of Maringá (UEM), Maringá, Brazil.

ORCID: http://orcid.org/0000-0002-7359-4562

E-mail:mcgm.uem@gmail.com

This is an open-access article distributed under the terms of the Creative Commons Attribution License 4.0 International. Available at: <http://creativecommons.org/licenses/by/4.0>. 